\title{
The Flood Narratives in Gen 6-9 and Darren Aronofsky's Film "Noah" "1
}

\section{Lydia LeE (North-West University, Potchefstroom CAMPUS)}

ABSTRACT

Since the release of Darren Aronofsky's film "Noah" in 2014, questions have been raised with regard to the relation between the film and the Bible. This article compares the flood stories in Gen 69 and Aronofsky's film "Noah." Probing some interesting and significant divergences between these two texts, I argue that the film "Noah" offers a good opportunity to discuss the open nature of the biblical texts, which often stimulates further transformations and interpretations.

KEY WORDS: Aranofsky, Noah, Gen 6-9, hermeneutics, Pentateuchal criticism, ancient Jewish interpretation.

\section{A INTRODUCTION}

In 2014, the award-winning director Darren Aronofsky transformed a biblical epic into a blockbuster film - "Noah." Informed by his Jewish upbringing, Aronofsky uses the film to create his own midrash on the Noah story. ${ }^{2} \mathrm{He}$ retells the biblical story of the flood recorded in Gen 6-9, narrating how Noah and his family have endured and survived the flood sent out by the Creator. The film includes a breath-taking scenery, dramatic plot, and above all complex characters. For the general public, a natural curiosity arises with regard to the

* Article submitted: 30/05/2016; peer reviewed: 23/06/2016; accepted: 11/07/2016. Lydia Lee, "The Flood Narratives in Gen 6-9 and Darren Aronofsky's 'Noah'," OTE 29/2 (2016): 297-317, doi: http://dx.doi.org/10.17159/23123621 /2016/ v29n2a7

My hearty thanks go to Dr. Nikolas Roubekas, who kindly proofread this article in detail. I also thank the anonymous reviewers, who offered helpful and encouraging comments on this article. Any surviving errors of fact are mine.

2 For Aronofsky's Jewish upbringing and his early attraction to the Genesis story of the flood, see the reports in Eric A. Goldman, "Noah' and the Jews," New Jersey: The Jewish Standard, released 28 March 2014, http://jewishstandard. timesofisrael.com/noah-and-the-jews/?/content/item/noah and the jews/30296;

Peter T. Chattaway, "The Jewish Roots of-and Responses to-Noah," Patheos, released 31 March 2014, http://www.patheos.com/blogs/filmchat/2014/03/the-jewishroots-of-and-responses-to-noah.html; Steven D. Greydanus, "Interview: 'Noah' Writer-Director Darren Aronofsky and Co-Writer Ari Handel," National Catholic Register, released 21 March 2014, http://www.ncregister.com/daily-news/interviewdarren-aronofsky-ari-handel. 
relation between the film and the Bible. ${ }^{3}$ A question that has been posed is whether the film corresponds to the biblical narrative.

In my opinion, the very term "biblical" is rather general. The Hebrew Bible itself is polyphonic. One aspect of the film that does not fit in well with Gen 6-9 can nevertheless be compatible with another text of the Hebrew Bible. For instance, the silent Creator in the film "Noah" stands in contrast to the rather talkative God in Gen 6-9. This portrayal of the Creator in the movie, however, seems compatible with the "God-less" scenarios in the Masoretic book of Esther, where the name of or the reference to God is not mentioned at all. ${ }^{4}$ The Masoretic book of Esther casts the limelight on the actions of the Jewish Queen Esther and her uncle Mordechai, which lead to the salvation of their people from the ethnic genocide. Similarly, the human characters form the

3 One screenwriter critically concludes that "the script of Noah is an uninteresting and unbiblical waste of a hundred and fifty million dollars that will ruin for decades the possibility of making a really great and entertaining movie of this Bible hero beloved by billions of religious believers, Jewish, Christian, and Muslim" (emphasis mine). For the whole of this critical review, see Brian Godawa, "Darren Aronofsky's Noah: Environmentalist Wacko," Thus Spake Godawa, released 29 October 2012, http://godawa.com/movies/sci-fi-fantasy/darrenaronofskys-noah-environmentalist-wacko/. For other controversies surrounding the film "Noah," see the reports in Cheryl K. Chumley, "Russell Crowe hits 'Noah' critics: 'Bordering on absolute stupidity," The Washington Times, released 27 March 2014, http://www.washingtontimes.com/news/2014/mar/27/russell-crowehits-noah-critics-bordering-absolute/; “Atheist 'Noah' director brags film is least biblical Bible movie ever," The Washingtom Times, released 24 March 2014, http://www.washingtontimes.com/news/2014/mar/24/atheist-noah-director-bragsfilm-least-biblical-bi/; Miriam Krule, "How Biblically Accurate Is Noah?" Slate: Browbeat, released 28 March 2014, http://www.slate.com/blogs/browbeat/2014/ 03/28/noah movie biblical accuracy how the darren aronofsky movie departs from.html; Kim Masters, "Rough Seas on 'Noah': Darren Aronofsky Opens Up on the Biblical Battle to Woo Christians (and Everyone Else)," The Hollywood Reporter, released 12 February 2014, http://www.hollywoodreporter.com/ news/rough-seas-noah-darren-aronofsky-679315.

4 This stands in contrast to the protagonists' extensive references and elaborate petitions to God in the Greek versions of Esther (e.g. LXX Esther C:1-30; AT Esther C:13-29). For an overview of the various explanations of God's absence in the Masoretic book of Esther, see Aaron Koller, Esther in Ancient Jewish Thought (Cambridge: Cambridge University Press, 2014), 98-9. See also Anne-Mareike Wetter, "Speaking from the Gaps: The Eloquent Silence of God in Esther," in Reflections on the Silence of God: A Discussion with Marjo Korpel and Johannes de Moor, ed. Bob Becking (Leiden: Brill, 2013), 153-67; Forrest S. Weiland, "Literary Clues to God's Providence in the Book of Esther," BSac 160 (2003): 34-47; Jonathan Grossman, Esther: The Outer Narrative and the Hidden Reading, Siphrut 6 (Winona Lake, Ind.: Eisenbrauns, 2011), 243-4. 
focus in the movie. Noah on the screen has to make a lot of efforts to interpret the divine will via dreams and visions, to deliberate whether to kill or to spare. ${ }^{5}$ If we take the book of Esther as part of the Hebrew Bible, if we accept that the seemingly absent God and the relatively active protagonists in the book of Esther are a comparable lens to look at the film, then the cinematic story of Noah can still be counted as "biblical" with regard to this particular aspect.

Rather than vaguely asking if the film is biblical, we can perhaps be more specific with our questions. We can narrow down our options, asking how the film compares specifically with the flood story in Gen 6-9. In broad outline, both the cinematic and biblical narratives share resemblances. Both of them begin the story with the antediluvian era, when human wickedness pervaded the earth; both continue the story with a gigantic ark floating on the surface of the water during the deluge; and both end the story with a surviving family in the cleansed land after the flood. In a detailed examination, however, they share some interesting and significant divergences. In what follows, I will only pick up a few examples. I think these examples helpfully illustrate the open nature of the flood story in Gen 6-9, which stimulates further creative transformations and interpretations in the film "Noah."

\section{B PRE-FLOOD}

I begin with an investigation of the causes of the flood given in Gen 6 . On the one hand, Gen 6:12, which is assigned to the priestly source (P), ${ }^{6}$ asserts that "all flesh had corrupted their way upon the earth." Indeed, it says "all flesh" ( בשר (2), which makes the animals equally guilty. Animals, like human beings, are subsumed under the category of "flesh" in $7: 15,16,21 ; 8: 17 ; 9: 11{ }^{7}$ They are supposed to be as corrupt as the human beings. The deluge is the retribution of God on the violence that dominates the whole world. On the other hand, Gen

5 The central role of Noah in discerning the divine will can be seen in two scenes of the film. In the first one, Methuselah, Noah's grandfather, responds to Noah's question about the dream he has received by saying: "Noah, you must trust that He speaks in a way that you can understand." In the second, Methuselah answers the request by Naamah, Noah's wife, for the procreation of her children after the flood by stating: "That choice is Noah's. Not mine. Not yours."

The whole pericope 6:9-22 belongs to the priestly source $(\mathrm{P})$, which is characterised by its use of אלהים as the divine name. This stands in contrast to the preferential deployment of יהוה as the divine name in the non-priestly segments (non-P) of the flood narrative. For a list of other differences between the priestly and non-priestly sources within Gen 6-9, see Gordon J. Wenham, Genesis 1-15, WBC 1 (Waco, Tex.: Word Books, Publ., 1987), 167; Erich Bosshard-Nepustil, Vor uns die Sintflut: Studien zu Text, Kontexten und Rezeption der Fluterzählung Genesis 6-9, BWANT 165 (Stuttgart: Kohlhammer, 2005), 43-52.

7 Cf. Wenham, Genesis 1-15, 142, 171; Bosshard-Nepustil, Sintflut, 44, n. 12. 
$6: 5$, belonging to another later stratum (non-P), presents a more limited view of the instigators of divine wrath. ${ }^{8}$ Instead of the corruption of "all flesh," it is specifically "the wickedness of mankind" (רעת האדם) that makes Yahweh so sorry that he decides to destroy the whole earth with a deluge. Questions thus arise: What is this "wickedness of mankind"? Are we supposed to link this wickedness to the preceding enigmatic account of the sexual union between the "sons of God" (בני האלהים) and the "daughters of mankind" (בנות האדם, cf. Gen 6:1-4)? Since the pericope in Vv. 1-4 contains a complete storyline, ${ }^{9}$ the

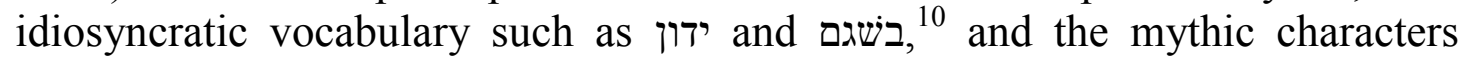
including "the sons of God" (הנפלים), (הני האלהים), "the Nephilim" and "the mighty men" (הגברים) that do not appear in the surrounding passages, ${ }^{11}$ many

8 Gen $6: 5$, along with 6:6-8, belongs to the non-P materials, which are likely dependent on the more complete $\mathrm{P}$ pericope in 6:9-22. The annihilation of the animals, creeping things, and birds of the sky alongside humanity in 6:7 (non-P) will be groundless if we do not take the corruption of "all flesh" in 6:12-13 (P) into account. In addition, Noah's gaining of divine favour in 6:8 (non-P) presupposes Noah's righteousness mentioned in 6:9 (P). For a fuller exposition of the dependency of 6:5-8 on 6:9-22, see Bosshard-Nepustil, Sintflut, 66-69. For the discussions concerning the presence of the priestly characteristics in Gen 6:7, see David Carr, Reading the Fractures of Genesis: Historical and Literary Approaches (Louisville, Ky.: Westminster John Knox, 1996), 57; Jean Louis Ska, "The Story of the Flood: A Priestly Writer and Some Later Editorial Fragments," in The Exegesis of the Pentateuch: Exegetical Studies and Basic Questions, FAT 66 (Tübingen: Mohr Siebeck, 2009), 15; both cited in Bernard M. Levinson, "A Post-Priestly Harmonization in the Flood Narrative," in The Post-Priestly Pentateuch: New Perspectives on its Redactional Development and Theological Profiles, ed. Federico Giuntoli and Konrad Schmid (Tübingen: Mohr Siebeck, 2015), 115 , n. 5.

9 David L. Petersen, "Genesis 6:1-4, Yahweh and the Organization of the Cosmos," JSOT 13 (1979): 48, who also cites Emil G. Kraeling, "The Significance and Origin of Gen 6:1-4,” JNES 6 (1947): 196.

10 Both words are hapax legomena. ידון probably derived from the Akkadian danānu "to be strong," and the whole phrase can be rendered as "my spirit shall not be strong in man forever..." בשגם is most naturally rendered as a causal phrase "in that also, since also," consisting of $ב+\underset{+}{+}$. For the fuller explanations and various other propositions in understanding these words, see Walter Bührer, "Göttersöhne und Menschentöchter: Gen 6,1-4 als innerbiblische Schriftauslegung," ZAW 123 (2011): 501-2; John Day, "The Sons of God and Daughters of Men and the Giants: Disputed Points in the Interpretation of Genesis 6:1-4," Hebrew Bible and Ancient Israel 1 (2012): 437-41.

11 For the difficulties related to the identifications of these characters, see Bührer, "Göttersöhne," 497-500, 503-5; Day, "The Sons of God," 427-30, 432-34; Archie T. Wright, The Origin of Evil Spirits: The Reception of Genesis 6.1-4 in Early Jewish Literature, 2nd ed. WUNT 198 (Tübingen: Mohr Siebeck, 2013), 62-76, 81-90. 
have considered it an even later intrusion into the present Flood narrative. ${ }^{12}$ Some propose that the passage in its original form served as an aetiological account of the Nephilim, who appear in Num 13:33 as the giants in the land of Canaan during the postdiluvian era. ${ }^{13}$ The presence of the possibly explanatory gloss "and also afterwards" (וגם אחרי כן) in Gen 6:4, as well as the translation of both "the Nephilim" and "the mighty men" as "giants" ( $\gamma$ í $\gamma \alpha v \tau \varepsilon \varsigma)$ in both Gen 6:4 and Num 13:33, seem to lend further support to this position. ${ }^{14}$ Viewing Gen 6:1-4 as merely an aetiological account, however, does not account for the passage's present function within the biblical flood narrative. Therefore, commentators further argue that the original passage has undergone a transformation, so that the addition now narrates a more concrete outburst of evil and disorder that accounts for the necessity of the destruction of humanity announced in the subsequent verses. ${ }^{15}$ Yet, strangely, the offense of humankind is not spelled out. In the present episode (vv. 1-4), the sons of God take the initiative to mingle with the mortal women. Why should humanity be punished for the act initiated by the sons of God, who are presumably the divine beings in the heavenly court? ${ }^{16}$ Ambiguities thus persist in identifying the actual cause of

12 For the justification of Gen 6:1-4 as post-priestly, see Bührer, "Göttersöhne," 495-506. Julius Wellhausen regards Gen 6:1-4 as antedating the priestly flood account, but he does highlight the episode as a "strange erratic boulder," so that "the connection between this piece and the story of the flood which follows it is of the loosest; and it is in entire disagreement with the preceding part of the Jehovist narrative" (Julius Wellhausen, Prolegomena to the History of Israel, trans. J. Sutherland Black and Allan Menzies [Edinburgh: Black, 1885], 317). Likewise, Martin Noth comments that "Gen 6:1-4 is so isolated in every respect that absolutely nothing can be said with certainty about the source identification of this passage" (Martin Noth, A History of Pentateuchal Traditions, trans. B. W. Anderson [Englewood Cliffs, N. J.: Prentice-Hall, 1972], 28, n. 83).

13 So Gerhard von Rad, Genesis: A Commentary, trans. John H. Marks (London: SCM Press, 1972), 115; Brevard S. Childs, Myth and Reality in the Old Testament (London: SCM Press, 1960), 56; Claus Westermann, Genesis, trans. David E. Green (London: T\&T Clark International, 1987), 43. Num 13:32b-33 contains the words of the Israelites who have spied in the land of Canaan: "All the people whom we saw in its midst were people of great size. And there we saw the Nephilim - the sons of Anak are part of the Nephilim - and we became like the grasshoppers in our own eyes, and so we were in their eyes."

14 The identification of the Nephilim as the mighty men also appears in Targum Onkelos and Targum Neofiti, which render the Nephilim in Gen 6:4 גיבריא and and respectively. See Wright, Origin, 83; Bührer, "Göttersöhne," 504, n. 60.

15 The commentators refer to this transformation as "demythologization." See, for example, Von Rad, Genesis, 115; Childs, Myth, 59. Westermann remarks that the offense involves "the transgression of human limits" (Westermann, Genesis, 43).

16 The same question is also posed in Ronald S. Hendel, "Of Demigods and the Deluge: Toward an Interpretation of Genesis 6:1-4," JBL 106 (1987): 16. For the 
the biblical deluge. How should "the wickedness of the mankind" mentioned in $6: 5$ be viewed in relation to the corruption of "all flesh" in $6: 12$ on the one hand, and to the sexual relations between gods and mortals in 6:14 on the other?

Here, the movie steps in and fills in the gap. It chooses to exonerate the animals from any guilt. ${ }^{17}$ According to the film, the animals are "the innocent." One night, Noah receives a terrifying vision, in which water engulfs and drowns many people. During his subsequent conversation with Methuselah, Noah's grandfather, ${ }^{18}$ Noah receives a second vision, in which the animals rise up from the water toward an enormous ship. When he regains his consciousness, Noah comes to the conclusion that the "innocent" and "pure" animals must be separated from the "wicked" and "foul" men. He thus undertakes the task to save the "innocent." 19 Why are the animals innocent? "Because they still live as they did in the Garden," clarifies the young Ila, Noah's adopted daughter. ${ }^{20}$ Here is an allusion to the pre-Fall state depicted in Gen 2-3.

Instead of focusing on the corruption of "all flesh," the film picks up the tradition that lays great stress on "the wickedness of mankind." In this way, the reason for the flood given in the film aligns less with Gen 6:12 (P), and more with Gen 6:5 (non-P). The film associates "the wickedness of mankind" with the carnivorous behaviour of humanity. ${ }^{21}$ In one scene where Noah enters the

understanding of the sons of God as the heavenly host, see Gen $1: 26 ; 2: 1 ; 3: 22$; $11: 7$; Job $1: 6 ; 2: 1 ; 38: 7$; Ps 29:1; 82:6; 89:7.

17 This thus stands in contrast to a rabbinic interpretation of Gen 6:12, which suggests that even the animals acted perversely, such that "the dog [copulated] with the wolf, the fowl with the peacock" (Gen. Rab. 28:8). In this article, all English translations of this midrash are taken from H. Freedman and Maurice Simon, trans. Midrash Rabbah: Genesis vol. 1 3rd ed. (London: Soncino Press, 1961), 228.

18 Methuselah is Enoch's son and Noah's grandfather in Gen 5:21, 25-27, 29. In 1 En. 106, Enoch presages the upcoming deluge and Noah's fate and relates them to Methuselah. This detail also plays out in the cinematic conversation between Methuselah and Noah.

19 In the cinematic narrative, Noah, aboard the ark, explains again to Japheth, his third son, that "innocent creatures are under our care," and "it's our job to look after them" (cf. Gen 1:28; 2:19-20).

20 The character Ila is not mentioned in the Hebrew Bible, but appears as the daughter of Manu, the flood hero and first man in the Indian mythology. For a fuller explanation, see Ingrid E. Lilly, "Ila on the Ark?: Emma Watson in Noah," Noah's Flood. Ancient Stories of Natural Cataclysm, released 28 January 2014, http://www.floodofnoah.com/\#!movie-emma-watson-as-ila-in-noah/c2yc.

21 According to Gen 1:29, humanity in the pre-flood world is supposed to be vegetarian: "Then God said: Behold, I have given you every plant yielding seed that is on the surface of all the earth, and every tree which has fruit yielding seed; it shall be food for you." Only after the flood is humankind allowed to eat meat: 
city in search of suitable wives for Ham and Japheth, the camera zooms in to reveal how covetous men hunt down beasts, slaughter animals, and trade girls for meat. Even more striking, the imagery of the sabre-toothed snake in Eden is superimposed over the bloody face of a man eating raw meat. At the end of this scene, Noah finds himself standing on the soil stained with blood shed by the wicked people. In addition, the film offers a specific interpretation of "the wickedness of mankind" that reflects a modern concern. Aronofsky presents the antediluvian evil as the industrial corruption. At the beginning of the film, the "great industrial civilization" built by Cain's descendants is associated with urban wickedness, ${ }^{22}$ and is set over and against "what is left of Creation" protected by Seth's descendants. ${ }^{23}$ One of Cain's descendants, Tubal-Cain, who appears as the first bronze and iron worker in Gen 4:22, becomes Noah's archenemy in the film. ${ }^{24}$ Under his leadership, humanity has learned to make weaponry and has been applying the newly learned skills to wreak havoc to the environment. Blinded by his greed for the tzohar mine, Tubal-Cain has killed Lamech. $^{25}$ The camera constantly zooms out to reveal the vast arid landscape, which is a result of human exploitations of the natural environment.

"Every moving thing that is alive shall be food for you; I give all to you, as I gave the green plant" (Gen 9:3). Cf. Wenham, Genesis 1-15, 192; Von Rad, Genesis, 131.

22 According to Gen 4, Cain is the first murderer (vv. 1-16), and also the first city-builder (v. 17). According to the early interpretations of Gen 4:15 and 4:24 found in Gen. Rab. 23:4 and Josephus' Ant. 1.63, Cain's descendants are all destroyed in the deluge as a punishment of Cain's sin. Cf. John Byron, Cain and Abel in Text and Tradition: Jewish and Christian interpretations of the First Sibling Rivalry, Themes in Biblical Narrative 14 (Leiden: Brill, 2011), 117-119, 122.

${ }_{23}$ As another son of Adam in place of Abel, Seth begins a righteous line of genealogy that leads to Noah (Gen 5:1-32). This Sethite genealogical line shares similarities as well as differences with the Cainite one (cf. Gen 4:17-24). Von Rad explains the parallelism between the two lists as follows: "The narrator needed the story and genealogy of Cain in order to show the increase of sin, and he needed the Sethite genealogy because it brought him down in the history of tradition directly to Noah and the Flood" (Genesis, 112).

24 According to Gen. Rab. 23:3, Tubal-Cain "perfected (tibbel) Cain's sin: Cain slew, yet lacked the weapons for slaying, whereas he was the forger of every cutting instrument, etc." Interestingly, the same rabbinic paragraph assigns Naamah, the sister of Tubal-Cain in Gen 4:22, as Noah's wife. Aronofsky's film follows this midrashic interpretation.

25 Cf. Gen 5:28. Lamech is also the name of Tubal-Cain's father (cf. Gen 4:19, 22). For two different approaches to the interrelationship between the two lists in Gen 4:17-24 and 5:1-32, see David T. Bryan, "A Reevaluation of Gen 4 and 5 in Light of Recent Studies in Genealogical Fluidity," ZAW 99 (1987): 180-88; Jan Christian Gertz, "The Formation of the Primeval History," in The Book of Genesis: 
Aronofsky further downplays the sexual innuendo latent within Gen 6:14. Ingeniously, the director reuses the images of the divine beings, the Nephilim, and the mighty men by conflating them. In the movie, the six-armed rocky giants are simultaneously the fallen divine beings called the Watchers. They come not to fornicate with the daughters of mankind, but to teach humanity about weapon-making. To underscore the evil nature of humanity, Aronofsky crafts a pitiful group of giants. Despite their physical strength and enormity, the Watchers are betrayed and hunted down by the people they have helped. Amiable enough, these giants decide to help Noah build the ark later on. Upon closer examination, Aronofsky does not present a whole new interpretation of the flood story. Many of the elements in the film are already present in the ancient story of 1 Enoch. ${ }^{26}$ Samyaza, one of the Watchers in the movie, is also the leader of the fallen angels in 1 Enoch $(6: 3,7 ; 8: 7)$. As in the film, the rebellious Watchers in 1 Enoch come to earth to teach the people "to make swords of iron and weapons and shields and breastplates and every instrument of war" $(8: 1){ }^{27}$ This knowledge of weaponry leads to more blood, violence, and oppression. The movie also draws from $1 E n$. 67:2, where a group of angels assists in the building of the ark: ${ }^{28}$

And now the angels are making a wooden (vessel), and when the angels have completed that task, I will put my hand upon it and protect

Composition, Reception, and Interpretation, ed. Craig A. Evans, Joel N. Lohr, and David L. Petersen, VTSup 152 (Leiden: Brill, 2012), 118-24.

261 Enoch is one of the Jewish pseudepigrapha dated to around 3rd century BCE. The composition contains a retelling of the story in Gen 6:1-4. For the scholarly introductions to 1 Enoch, see John J. Collins, The Apocalyptic Imagination: An Introduction to Jewish Apocalyptic Literature, 2nd ed. (Grand Rapids, Mich.: William B. Eerdmans Publishing Company, 1998), 43-84; James C. Vanderkam, "The Book of Enoch and the Qumran Scrolls," in The Oxford Handbook of the Dead Sea Scrolls, ed. John J. Collins and Timothy H. Lim (Oxford: Oxford University Press, 2010), 254-277; George W. E. Nickelsburg, 1 Enoch 1: A Commentary on the Book of 1 Enoch, Chapters 1-36, 81-108 (Hermeneia, Minn.: Fortress, 2001), esp. 165-228.

27 This tradition in 1 Enoch renders 'Aśa'el as the leader of the Watchers, and their primary sin is not "marriage with humans" but "improper revelation" (cf. 1 En. 65:6-7). See Collins, Imagination, 49-50. Interestingly, scholars have made a connection between 'Aśa'el in 1 En. 8:1 and Tubal-Cain in Gen 4:22. See George W. E. Nickelsburg, “Apocalyptic and Myth in 1 Enoch 6-11," JBL 96 (1977): 399; Wright, Origin, 107.

28 In the Ethiopic version of 1 En. 89:1, Noah was turned into an angel in order to build the ark. See Devorah Dimant "Noah in Early Jewish Literature," in Biblical Figures outside the Bible, ed. Michael E. Stone and Teodore A. Bergren (Harrisburg, Pa.: Trinity Press International, 1998), 134. 
it. And from it will come the seed of life, and a change will take place, so that the earth will not remain desolate. ${ }^{29}$

To be sure, the Enochic texts have their own agenda, with a lot of other sexual and monstrous details that are not present in the movie. ${ }^{30}$ In 1 Enoch, the mingling between the Watchers and the mortal women brings forth hybrid giants who commit iniquitous deeds, such as cannibalism and blood-drinking, so that the earth finally "brought accusation against the lawless ones" (7:1-6). ${ }^{31}$ As Vanderkam states: "The angelic sin was a fundamental tenet in the thought of Enochic Judaism ... humans became the victims of a pre-existing evil so powerful they could not stand against it." 32 What Aronofsky does is that he creatively draws elements from these Enochic sources, combining them with a biblical framework, in order to elicit his own perception about the cause of the flood. In the movie, neither the animals nor the Watchers are responsible for the deluge. Humanity alone engenders the environmental and social degradations so much that the Creator lashes out and demands his justice. Here comes the flood.

\section{THE DELUGE}

Some of the most memorable scenes from the film happen in the ark. Yet, Gen 6-9 is comparatively mute about what happens to the human characters on board during the deluge. The first flood account in the Hebrew Bible is preoccupied with the construction and the measurements of the ark, the number and kind of animals on board, and the time period of the flood. In the priestly narrative, Noah receives a specific divine instruction to build the ark from gopher

29 All English translations of 1 Enoch are drawn from George W. E. Nickelsburg, 1 Enoch: The Hermeneia Translation (Minneapolis, Minn.: Fortress Press, 2012).

${ }^{30}$ For further details, see Matthew Goff, "Monstrous Appetites: Giants, Cannibalism and Insatiable Eating in Enochic Literature," Journal of Ancient Judaism 1 (2010): 19-42; and "Before the Genesis flood: Enoch's Monstrous Exegesis (Part I)," Noah's Flood. Ancient Stories of Natural Cataclysm, released 24 January 2014, http://www.floodofnoah.com/\#!monstrous-enoch-watchers/c123v.

31 Cf. Jub. 5:1-2. The giants are called the "evil spirits" (1 En. 15:1-16:3), or are characterised as foolish (Bar 3:26-28; Sir 16:7) or proud (Wis 14:6; 3 Macc 2:4). But see Matthew Goff's essay ("Ben Sira and the Giants of the Land: A Note on Ben Sira 16:7," JBL 129 (2010): 645-655), who argues that the giants in Sir 16:7 is described in the language of Gen $6: 4$ but actually refers not to the antediluvian hybrid offspring but to the pre-monarchic Canaanite leaders.

32 Vanderkam, "Enoch," 265. So also Collins, Imagination, 52, who states: "It [the story of the Watchers] provides a paradigm for the origin of sin and evil. The distinctive aspect of this paradigm lies in the role of supernatural agents, in this case the fallen angels." Cf. Wright, Origin, 131, who asserts that "the chief aim of 1 Enoch 1-16 is to demonstrate and accentuate the nature of the sin of the angels and, secondarily, humans." 
wood (6:14). ${ }^{33}$ The ark should be 300 cubits long, 50 cubits wide, and 30 cubits high (6:15). ${ }^{34}$ More perplexingly, the texts call for different numbers of animals to go into the ark. On the one hand, without specifying the kind of animals, God in the P account prescribes two pairs of animals to enter the ark (6:19-20; $7: 15)$. On the other hand, Yahweh in the non-P narrative specifies two pairs of unclean animals plus seven pairs of clean to be imported into the ark (7:2-3). ${ }^{35}$ Equally intriguing, the texts offer different temporal markers for the flood. The P segment offers a time span of 150 days for the duration of water coming from "the fountains of the great deep" and "the floodgates of the sky" (7:11, 24; $8: 2 \mathrm{a}, 3 \mathrm{~b}-5,13-14) .{ }^{36}$ Meanwhile, the non-P segment mentions 40 days and 40 nights of "rain" $(7: 4,12,17 ; 8: 2 \mathrm{~b}, 6)$. As seen, these inconsistencies or duplications have been assigned to different textual sources, either P or non-P. Yet, we are left with a gap in the Genesis story: What happens exactly when Noah and his family are on board? How can the ark sustain all the animals without them killing each other during the voyage?

Imaginatively, the film takes up the gap and fills it up with some of the most interesting and dramatic events. Inside the ark, a special herbal incense is used to sedate the animals. Therefore, the animals in the film sleep peacefully throughout their voyage during the inundation. This cinematic depiction of the deployment of the herbal incense by Noah's family is probably influenced by the tradition related to $J u b$. 10:14, in which Noah was given the angelic

33 Gopher is a hapax legomenon in the Hebrew Bible. For the different renditions of this word in the LXX, Vulgate, and Targum, see Wenham, Genesis 1-15, 172-3.

34 The details regarding the construction of the ark are attributed to the P-source. The non-P materials do not mention the construction but already presuppose the completion of the ark (Gen $7: 1$; cf. 6:14, 21). Further terminological similarities (cf. $6: 19-20 / / 7: 3 ; 6: 18 / / 7: 1 ; 6: 22 / / 7: 5$ ) add to the likelihood that the non-P account in 7:1-5 supplements the $\mathrm{P}$ account in 6:9-22. For a fuller account of this direction of dependency, see Bosshard-Nepustil, Sintflut, 62-6.

35 Contra J. David Pleins, When the Great Abyss Opened: Classic and Contemporary Readings of Noah's Flood (Oxford: Oxford University Press, 2003), 28, who incorrectly writes "two pairs of clean animals plus seven pairs of unclean." The non-P's addition of the animals aboard the ark as well as the differentiation between the clean and the unclean cohere with the subsequent non-P episode, where clean animals and birds are required for making sacrifice (8:20). Extra pairs of birds are needed to search for the dry land (8:7-12). Gen 7:2-3 (non-P) is thus more precise than Gen 6:19-20 (P). See Wenham, Genesis 1-15, 176-177; Bosshard-Nepustil, Sintflut, 64. For the argument that Gen 7:8-9 represents an even later attempt to harmonize the accounts in 6:19-20 and 7:2-3, see Levinson, "Harmonization," esp. 120-122 (contra Ska, "Flood," 3-6).

${ }^{36}$ This inconsistency is also noted in Levinson, "Harmonization," 117-8; Bosshard-Nepustil, Sintflut, 44; Wenham, Genesis 1-15, 167. 
knowledge, "so that he might heal by means of herbs of the earth." ${ }^{37}$ Behind the solid walls of the ark, Noah copes with darkness with special illuminating stones, which lit up the whole ark day and night. These magical stones are called the tzohar. In Gen 6:16a, God instructs Noah: "A צהר (tzohar) you shall make for the ark." The noun tzohar in this verse is a hapax legomenon in the Hebrew Bible, and it can be understood in parallel with the ("covering" or "roof") in Gen 8:13 or the "חלון (window" or "skylight") in Gen 8:6. ${ }^{38}$ Aronofsky reimagines the tzohar in the cinematic ark by following a midrashic interpretation of the verse:

"A light (tzohar) shalt thou make for the ark" (VI, 16) ... R. Abba b. Kahana said: It [tzohar] means a skylight; R. Levi said: A precious stone. R. Phinehas said in R. Levi's name: During the whole twelve months that Noah was in the Ark he did not require the light of the sun by day or the light of the moon by night, but he had a polished gem which he hung up: when it was dim he knew that it was day, and when it shone he knew that it was night. ${ }^{39}$

Through the creative mixture of traditions, the movie audience is led into a magical world, where the impossible survival inside the ark during the deluge is rendered possible.

More human dramas are in store inside the cinematic ark. Tubal-Cain, the leader of Cain's descendants, has successfully sneaked into the ark. When he first meets Ham outside of the ark, he introduces himself as the "king of the earth." His egocentric worldview is blatantly expressed when he claims: "This all belongs to me. This land. This forest." 40 He has little regard for the Creator: "Nobody has heard from Him since He marked Cain." "41 He believes only in himself, since men are "cursed to struggle by the sweat of our brow to sur-

37 Cf. 1 En. 7:1, in which the Watchers taught humans "the cutting of roots and plants." The tradition that Noah received the angelic knowledge of herbs is recorded in "various Greco-Roman, Byzantine, and medieval Jewish Hebrew writings," as noted in Dimant, "Noah," 134, esp. n. 54.

38 Bosshard-Nepustil, Sintflut, 74. Cf. Gertz ("Primeval History," 125), who states that "in the current context the priestly צחר in Gen 6:16 and the non-P מכסר in Gen 8:6b, as well as the priestly פתח in Gen 6:16 and the non-P 8:13b, are identified." Note that Bosshard-Nepustil and Gertz have different views about the genetic relationship between the P and non-P materials in Gen 6-9.

39 Gen. Rab. 31:11. This rabbinic embellishment of the biblical narrative is also noted in Pleins, Abyss, 35.

40 In the movie, his ego is also reflected when he shouts angrily to the Creator: "I give life and take life away, as you do. Am I not like you?" Herein lies an allusion to Job 1:21, which states Yahweh's all-encompassing sovereignty: "Yahweh gave and Yahweh has taken away."

41 Cf. Gen 4:15. 
vive." 42 Even inside the ark, Tubal-Cain is impenitent, claiming that "a man isn't ruled by heavens. A man is ruled by his will." He still thinks that he alone is the definition of justice, and that the whole world should be subjugated under his own definition of justice. He justifies his killing and devouring of the animals in the ark by claiming that "the animals serve us." 43 Driven by his lust for the beasts and women aboard the ark, he attempts to murder Noah.

Another plan of homicide is also brewing in the mind of Noah's second son, Ham. In the film, Ham has always been the most inquisitive character. Unlike his vegetarian family, he shows particular interests in hunting and weapons. When Noah decides to take Shem to find Methuselah, the young Ham protests: "Why can't I come?" Having peeped at the hot and wet kisses between Shem and Ila in the forest, the adolescent Ham longs for his own wife. ${ }^{44}$ When Noah has failed to find Ham a wife, the latter ventures into the city alone in search of his dream partner. Just when Ham thinks that he has found the right one - a girl by the name of $\mathrm{Na}$ 'el - the storm comes. ${ }^{45}$ On their route to escape the storm, Noah arrives but fails to rescue $\mathrm{Na}$ 'el and thus forces her to be trampled by the stomping mob who all want to rush into the ark. In retaliation to Noah's failures, Ham lets his father's archenemy hide inside the ark. He feeds Tubal-Cain and assists the stowaway in fighting against his own father. In doing this, Ham seeks vengeance and justice.

The most elaborate and extreme attempt in annihilating humanity comes from Noah the protagonist of the movie. Noah has long decided that none of the human beings is righteous. Prior to their boarding on the ark, he tells his wife that "wickedness is in all of us." Humanity does not deserve to live. Aboard the ark, Noah retells the creation story his father told him, ending it with Cain's murder of Abel. In this cinematic retelling, the dark silhouette of Cain morphs into different kinds of soldiers, representing the crimes of humanity through the ages. ${ }^{46}$ Noah subsequently shares with his children the following views: "Sin has walked within us"; "man did this"; "mankind must end." Noah believes that, after the flood and after saving the animals and plant life,

42 Cf. Gen 3:17-19.

43 Cf. Gen 1:28.

44 Cf. Gen 9:22, where Ham's voyeurism is noted.

45 The name "Na'el" is likely adapted from the name of Ham's wife (Na'eltama'uk or Ne'elatama'uk) in Jub. 7:14. James L. Kugel (A Walk through Jubilees: Studies in the Book of Jubilees and the World of Its Creation, Journal for the Study of Judaism 156 [Leiden: Brill, 2012], 70) suggests that the name in Jubilees probably consists of two elements: "the hereditary land of..." (נחלת) and the actual name of Ham's wife "amauk."

46 Noted also in Kent L. Brintnall, "What Noah Got Right, That Noah Got Wrong," Noah's Flood. Ancient Stories of Natural Cataclysm, released 30 March 2014, http://www.floodofnoah.com/\#!noah-movie-noah-was-right/c1iz9. 
he and his family are to die alongside the rest of humanity. To an extreme, going against all of his family, he actively seeks to kill the twin babies given birth by Ila. ${ }^{47}$ Noah thinks that human death and destruction become the only way to carry out the Creator's justice. In sum, Aronofsky's characters all seek and yearn for their own definitions of justice. Ironically, in their most earnest quests for justice, each one's actions become the very evil in eyes of the rest. ${ }^{48}$ What stands out most starkly in this episode is the following message: That evil persists inside the very ark!

\section{POST-FLOOD}

This persistence of human evil depicted in the film, however, does not deviate too much from what can be gleaned from Gen 6-9. We are too often preoccupied with the fantastic "rainbow covenant" recorded in Gen 9:1-17. In this $\mathrm{P}$ pericope, God blesses Noah and his family: "Be fruitful and multiply, and fill the earth" (v. 1, cf. v. 7). ${ }^{49}$ God is generous enough to establish a rainbow covenant with Noah, his descendants, and all the living creatures on earth (vv. 817). ${ }^{50}$ He promises that never again will he send a flood to destroy the earth. It seems that all unpleasant things have been cleansed and washed away by the deluge. It appears that "everybody lives happily ever after"; 51 that everything is

47 A number of scholars observe a merging between this scene and the Akedah or the Binding of Isaac in Gen 22:1-19. See, for instance, Erica L. Martin, "Darren Aronofsky's Noah and Jewish Tradition," Noah's Flood. Ancient Stories of Natural Cataclysm, http://www.floodofnoah.com/\#!noah-movie-jewish-tradition /c1yem; Sarah Schectman, "What Was Biblical in the Movie Noah?" Noah's Flood. Ancient Stories of Natural Cataclysm, http://www.floodofnoah.com/\#!noah-movie-what-was-biblical/c123y; Robert K. Johnston, "The Biblical Noah, Darren Aronofsky's Film Noah, and Viewer Response to Noah: The Complex Task of Responding to God's Initiative," Ex Auditu 30 (2014): 95.

48 For example, when Noah decides to carry out the infanticide, he alienates from all of his family members. Shem shouts to Noah: "Are you mad? This is my child." The usually obedient wife Naamah tearfully questions Noah's concept of justice: "How is this just?" She defies Noah's decision to kill their grandchildren: "Boy or girl. I will never forgive. And you will die alone. Not just alone, but hated! Hated by everyone you love. That is just."

49 Cf. the exact Hebrew wording פרו ורבו ומלאו את הארץ in Gen 1:28 (P). See also Von Rad, Genesis, 131.

50 The covenant is also mentioned in Gen 6:18 (P).

51 Dana Perino, quoted in Travis Gettys, "Jon Stewart mocks childish fantasies of 'Noah' critics: Happily ever after? 'Everybody drowns!'” Raw Story, released 9 April 2014, http://www.rawstory.com/2014/04/jon-stewart-mocks-childish-fantasiesof-noah-critics-happily-ever-after-everybody-drowns/. 
"fine and dandy" after the flood has ceased. ${ }^{52}$ The slate has been wiped clean. Yet, we forget the surrounding passages, which preserve another stream of tradition that holds a bleaker future for humanity. In a non-P paragraph that reinterprets the priestly ending of the flood, Yahweh states: ${ }^{.3}$

I will never again curse the ground on account of man, although the intent of man's heart is evil from his youth; and I will never again destroy every living thing, as I have done (Gen 8:21).

From this divine speech, it can be seen that Yahweh is merciful enough, so that he will never send the flood again. Still, it is explicitly stated that the problem of humanity is not solved. Evil will continue to plague the mortal world. The end of the flood, as depicted in Gen 9:20-27 (non-P), sustains this pessimistic outlook. $^{54}$ Not all live happily ever after. After the dissipation of the water,

52 Quoted from the children's song "Rise and Shine and Give God the Glory, Glory!" The whole song is cited in Johnston, "God's Initiative," 90.

53 Contra Wenham, Genesis 1-15, 188, Bosshard-Nepustil, Sintflut, 69-71, has offered a compelling argument for the dependency of 8:20-22 (non-P) on 9:1-17 (P). First, Bosshard-Nepustil suggests that Yahweh's refrain from cursing the ground (v. 21) finds its counterpart in v. 22, where the seasons and harvest will be restored to order. Meanwhile, Yahweh's promise not to destroy every living thing (v. 21) finds no counterpart in vv. 20-22, but presupposes the procreation of mankind and living animals envisioned in 9:1-7 (P). Second, Bosshard-Nepustil argues that the lowly estimation of the ground and mankind reflected in 8:21 (non-P) presupposes the corruption of all flesh in 6:11-13 (P).

54 Both Von Rad, Genesis, 135, and Noth, Pentateuchal Traditions, 262, categorise 9:18-27 as "Yahwistic" or J-source and treat it as earlier than the surrounding priestly account. However, Jan Christian Gertz convincingly argues that Gen 9:20 27 should be seen as a non-P segment added later to the priestly narrative, in order to build a transition from creation, its reversal and rebuilding to the emergence of various ethnic groups. He notes many lexical parallels between 9:20-27 and the non-priestly account of creation in Gen 2-4. For instance, Noah is called איש האדמה in Gen 2:5, 6, 7, 9, 19; 3:17, 19, 23; 4:3, $10,11,12,14$ (cf. 5:29). נטע in 9:20 recalls Yahweh's planting of the garden (Gen 2:8), and ידע 9:24 evokes the sexual relationship of the couples in Gen 2:9, 17; $3: 5,22 ; 4: 1,9,17,25$. Given that Gen 9:18-19 and 9:28-29 parallel the priestly stratum (cf. 5:32), and that the reference to the two brothers in 9:22 (non-P) clearly presupposes the references to Shem and Japheth mentioned in 9:18 (P), Gertz thus draws the conclusion: "Der Abschnitt Gen 9,18-19 geht auf einen nachpriesterschriftlichen Verfasser zurück" (93, cf. 89). For further explications, see Jan Christian Gertz, "Hams Sündenfall und Kanaans Erbfluch: Anmerkungen zur kompositionsgeschichtlichen Stellung von Gen 9,18-29," in "Gerechtigkeit und Recht zu üben" (Gen 18,19): Studien zur altorientalischen und biblischen Rechtsgeschichte, zur Religionsgeschichte Israels und zur Religionssoziologie: Festschrift für Eckart Otto zum 65. Geburtstag, ed. Reinhard Achenbach and 
Noah lays in a state of drunken stupor (9:21). Ham "saw the nakedness of his father" (9:22). This image has been variously interpreted as related to Ham's voyeurism, ${ }^{55}$ his castration of his father Noah, ${ }^{56}$ Ham's sexual abuse of Noah, ${ }^{57}$ or his sexual violation of his own mother (i.e. Noah's wife). ${ }^{58}$ Subsequently, Noah curses the son of Ham, Canaan, to be "a servant of servants" (9:25). This verse has been cited through the centuries to justify the exploitation of Africans and African-Americans. ${ }^{59}$ As it becomes evident, not everybody is happy. The non-P ending of the flood thus corrects the over-optimistic outlook in 9:1-17 (P), which envisions a universal blessing for Noah's descendants and all flesh, ${ }^{60}$ by putting forward a pessimistic but sober view of human nature. ${ }^{61}$

Initially, I thought that the ending of the movie, unlike the aforementioned non-P paragraphs, was too soft. Yes, Noah in the film is also inebriated. The film further supplies a reason for Noah's post-deluge drunkenness: to escape his sense of guilt. Noah, having spared the life of his grandchildren, thinks that he has failed the Creator's prescribed task to annihilate the whole of

Martin Arneth, BZABR 13 (Wiesbaden: Harrossowitz, 2009), 81-95, esp. 84-90, 93-5.

55 So LXX Gen 9:20-29; Philo, $Q G$ 2.70; Josephus, Ant. 1.140-142. For the argument that Ham's gazing stole away Noah's sexual potency, see H. Hirsch Cohen, The Drunkenness of Noah (Alabama: University of Alabama Press, 1974). For a discussion of Cohen's proposition, see Pleins, Abyss, 130-32.

56 Cf. b. Sanh. 70a; Gen. Rab. 36:7. For the argument that the castration tradition is a post-biblical invention to rationalise Gen 9:20-29, see Albert I. Baumgarten, "Myth and Midrash: Genesis 9:20-29," in Christianity, Judaism and Other Greco-Roman Cults: Part Three: Judaism before 70, ed. Jacob Neusner (Leiden: Brill, 1975), 55-71.

57 Cf. b. Sanh. 70a; Gen. Rab. 36:7. For a list of bibliography advocating this view, see Nicholas Odhiambo, "The Nature of Ham's Sin,” BSac 170 (2013): 154, n. 3.

58 So Frederick W. Bassett, "Noah's Nakedness and the Curse of Canaan: A Case of Incest?" VT 21 (1971): 235; John Sietze Bergsma and Scott Walker Hahn, "Noah's Nakedness and the Curse on Canaan (Genesis 9:20-27)," JBL 124 (2005): 25-40. The latter article also lucidly discusses the aforementioned three interpretations of Ham's act.

59 See the discussions in Edwin M. Yamauchi, Africa and the Bible (Grand Rapids, Mich.: Baker Academic, 2004), 19-33; Pleins, Abyss, 132-138; David M. Goldenberg, The Curse of Ham: Race and Slavery in Early Judaism, Christianity, and Islam (Princeton: Princeton University Press, 2003), 141-177.

60 Gertz, "Hams Sündenfall," 95, concludes: "Der Verfasser von Gen 9,18-29 hat die durch die priesterschriftlichen Texte in die biblische Urgeschichte eingezogenen utopischen Züge mit einer gehörigen Portion Realismus konfrontiert."

${ }^{61}$ This stands in contrast to the surrounding ancient Near Eastern flood myths, which often end positively with the deification of the flood heroes (e.g. Ziusudra, Utnapishtim, Berossus's Xisouthros). Noted in Baumgarten, "Myth," 58; Pleins, Abyss, 102, 107, 109; Wenham, Genesis 1-15, 166. 
humanity. However, after a short conversation with the sweet and compassionate Ila, Noah is able to pull himself together and reconcile with his wife. Ila told Noah: "He [the Creator] showed you the wickedness of men ... But then you saw goodness too ... And you chose mercy. You chose love ... Help us to do better this time. Help us start again." The scene then changes to reveal the joining hands of Noah and Naamah in the farmland. Noah's final blessing given to his sons also includes the rebellious Ham. ${ }^{62}$ Every problem seems to be solved. Life seems to return to a state of harmony.

It is not until I think back at the eerie snake-skin tefillin wrapped around Noah's forearm during his giving of the divine blessing that I finally seem to grasp what Aronofsky is trying to convey. Binding tefillin on the arm and on the forehead is one of the Jewish practices, derived from Deut 6:8 and being passed down from generation to generation. ${ }^{63}$ Throughout the film, the snakeskin tefillin has appeared at four crucial junctures. The beginning of the film shows that the epidermis comes from the infamous snake in Paradise. Adam picks up the epidermis shed by the snake when Eve succumbs to the temptation of the forbidden fruit. Later, Tubal-Cain forcefully seizes the snake-skin tefillin when he murders Noah's father Lamech. The snake-skin tefillin flashes another time when Ham stabs Tubal-Cain at his back aboard the ark. The dying TubalCain hands over the epidermis and enigmatically whispers to Ham: "Now you are a man." The receipt and transfer of the snake-skin tefillin is always accompanied by temptation, bloodshed, and violence. It is therefore disconcerting when Noah binds the glowing tefillin-like strip, which Ham has returned to him, on his arm in his blessing to the sons. The act speaks to the fact that the blessing will always be accompanied by the curse. Johnston's over-optimistic interpretation that "the wrapped snakeskin is a reminder of the innocence and goodness of Eden" is only partially correct. ${ }^{64}$ The epidermis not only brings to mind the "innocence and goodness" in Paradise, but also underscores the Fall and human inability to return to that pristine state again. Godawa correctly argues that the serpentine imagery in the Hebrew Bible and the New Testament is almost always negative. ${ }^{65}$ However, Godawa goes too far in claiming that Aronofsky subverts the biblical serpentine imagery by fashioning the cinematic

62 In his blessing, Noah said: "That birthright was passed down to us. To my father, then to me, and to my sons, Shem, Japheth, and Ham."

63 Deut 6:6, 8 states: "And these words, which I am commanding you today, shall be on your heart ... and you shall bind them as a sign on your hand and they shall be as frontals on your forehead." Cf. Johnston, "God's Initiative," 99, n. 22.

64 Johnston, "God's Initiative," 99, n. 22.

65 For example Gen 3:1, 15; Num 21; John 8:44-45. The serpent is also related to the monsters of chaos, such as Rahab (Job 9:13; 26:12; Ps 89:10; Isa 30:7; 51:9) and Leviathan (Job 3:8; 41:1; Isa 27:1; Ps 74:14; 104:26). 
serpent positively. ${ }^{66}$ As the foregoing analysis of the cinematic appearances of the snake-skin tefillin has shown, Aronofsky, contrary to Godawa's assertion, actually does not deny but acknowledges the uncanny negativity embedded in the serpentine talisman. In accordance with Gen 8:21 (non-P), the final scene of the movie reveals that the problem of evil, symbolised via the serpentine epidermis, is not resolved. ${ }^{67}$ From generation to generation, humanity will continuously be plagued by this problem. As the haunting lullaby "Mercy is" plays along at the end of the movie, ${ }^{68}$ we cannot help but think that Aronofsky is conveying to us this message, which is also embedded in the biblical text: perhaps what makes us survive in this ever problematic world is that bit of mercy.

\section{E CONCLUSION}

To summarise, Aronofsky's film "Noah" is one truly excellent example of the retelling of the flood story in Genesis 6-9. To be acknowledged, the biblical texts do impose boundaries at various junctures. The director of the movie has followed the broad framework of Gen 6-9 in relating the adventure of Noah's family before, during, and after the flood. Meanwhile, the above examination shows that the biblical texts also contain many gaps that render creative transformations and reinterpretations possible. Thus Aronofsky has culled from a range of biblical and extra-biblical sources (e.g. Gen 1-3; 1 Enoch; Jubilees; Genesis Rabbah) in order to share his insights about goodness, wickedness, mercy, judgment, divine will, and human choices. ${ }^{69}$ At the end of the film, Ila enlightens Noah: "The choice was put in your hands because He [the Creator] put it there. He asked you to decide if we were worth saving." The conveyed message is thus that, just like the movie director and characters, we in our lives also need to choose how we want to understand, interpret, update, and live out those biblical gaps.

66 Brian Godawa, "The Subversion of the Serpent in Aronofsky's Noah," Thus Spake Godawa, released 4 April 2014, http://godawa.com/movies/sci-fi-fantasy/subversion-serpent-aronofskys-noah/. For a view similar to Brian Godawa, see Brian Mattson, "Sympathy for the Devil," Dr. Brian Mattson The Website: Journal, released 31 March 2014, http://drbrianmattson.com/journal/2014/3/31 /sympathy-for-the-devil.

67 This lingering problem of evil is also reflected in $1 \mathrm{En}$. 15:8-16:1; Jub. 7:27; 10:1-14, where the evil spirits coming out of the dead giants will continue to plague the children on earth. See Dimant, "Noah," 133.

68 The lyrics of the lullaby is reprinted in Johnston, "God's Initiative," 109.

69 For an interview with Aronofsky's co-writer, Ari Handel, which summarizes these themes in the movie, see Michael Dunaway, "On Noah and Faith: A Conversation with Ari Handel," Paste, released 25 March 2014, https://www.pastemagazine.com/articles/2014 103/on-noah-and-faith-a-conversation-with-ari-handel.html. 


\section{BIBLIOGRAPHY}

Bassett, Frederick W. "Noah's Nakedness and the Curse of Canaan: A Case of Incest?" Vetus Testamentum 21 (1971): 232-37.

Baumgarten, Albert I. "Myth and Midrash: Genesis 9:20-29." Pages 55-71 in Christianity, Judaism and Other Greco-Roman Cults: Part Three: Judaism before 70. Edited by Jacob Neusner. Leiden: Brill, 1975.

Bergsma, John Sietze, and Scott Walker Hahn. "Noah's Nakedness and the Curse on Canaan (Genesis 9:20-27)." Journal of Biblical Literature 124 (2005): 25-40.

Bosshard-Nepustil, Erich. Vor uns die Sintflut: Studien zu Text, Kontexten und Rezeption der Fluterzählung Genesis 6-9. Beiträge zur Wissenschaft vom Alten und Neuen Testament 165. Stuttgart: Kohlhammer, 2005.

Brintnall, Kent L. "What Noah Got Right, That Noah Got Wrong." Noah's Flood. Ancient Stories of Natural Cataclysm. Released 30 March 2014. http://www. floodofnoah.com/\#!noah-movie-noah-was-right/cliz9.

Bryan, David T. "A Reevaluation of Gen 4 and 5 in Light of Recent Studies in Genealogical Fluidity." Zeitschrift für die alttestamentliche Wissenschaft 99 (1987): 180-88.

Bührer, Walter. "Göttersöhne und Menschentöchter: Gen 6,1-4 als innerbiblische Schriftauslegung." Zeitschrift für die alttestamentliche Wissenschaft 123 (2011): 495-515.

Byron, John. Cain and Abel in Text and Tradition: Jewish and Christian interpretations of the First Sibling Rivalry. Themes in Biblical Narrative 14. Leiden: Brill, 2011.

Carr, David. Reading the Fractures of Genesis: Historical and Literary Approaches. Louisville, Ky.: Westminster John Knox, 1996.

Chattaway, Peter T. "The Jewish Roots of - and Responses to - Noah." Patheos. Released 31 March 2014. http://www.patheos.com/blogs/filmchat/2014/03 the-jewish-roots-of-and-responses-to-noah.html.

Childs, Brevard S. Myth and Reality in the Old Testament. London: SCM Press, 1960.

Chumley, Cheryl K. "Atheist 'Noah' director brags film is least biblical Bible movie ever." The Washington Times. Released 24 March 2014. http://www. washingtontimes.com/news $/ 2014 / \mathrm{mar} / 24 /$ atheist-noah-director-brags-filmleast-biblical-bi/.

. "Russell Crowe hits 'Noah' critics: 'Bordering on absolute stupidity.", The Washington Times. Released 27 March 2014. http://www. washingtontimes.com/news/2014/mar/27/russell-crowe-hits-noah-criticsbordering-absolute/.

Cohen, H. Hirsch. The Drunkenness of Noah. Alabama: University of Alabama Press, 1974.

Collins, John J. The Apocalyptic Imagination: An Introduction to Jewish Apocalyptic Literature. 2nd ed. Grand Rapids, Mich.: William B. Eerdmans Publishing Company, 1998.

Day, John. "The Sons of God and Daughters of Men and the Giants: Disputed Points in the Interpretation of Genesis 6:1-4." Hebrew Bible and Ancient Israel 1 (2012): 427-47. 
Dimant, Devorah. "Noah in Early Jewish Literature." Pages 123-150 in Biblical Figures outside the Bible. Edited by Michael E. Stone and Teodore A. Bergren. Harrisburg, Pa.: Trinity Press International, 1998.

Dunaway, Michael. "On Noah and Faith: A Conversation with Ari Handel." Paste. Released 25 March 2014. https://www.pastemagazine.com/articles/2014/ 03/on-noah-and-faith-a-conversation-with-ari-handel.html.

Freedman, Harry, and Maurice Simon. Translation of Midrash Rabbah: Genesis. Vol. 1, 3rd ed. London: Soncino Press, 1961.

Gertz, Jan Christian. "The Formation of the Primeval History." Pages 107-35 in The Book of Genesis: Composition, Reception, and Interpretation. Edited by Craig A. Evans, Joel N. Lohr, and David L. Petersen. Supplement to Vetus Testamentum 152. Leiden: Brill, 2012.

"Hams Sündenfall und Kanaans Erbfluch: Anmerkungen zur kompositionsgeschichtlichen Stellung von Gen 9,18-29." Pages 81-95 in "Gerechtigkeit und Recht zu üben" (Gen 18,19): Studien zur altorientalischen und biblischen Rechtsgeschichte, zur Religionsgeschichte Israels und zur Religionssoziologie: Festschrift für Eckart Otto zum 65. Geburtstag. Edited by Reinhard Achenbach and Martin Arneth. Beihefte Zeitschrift für altorientalische und biblische Rechtsgeschichte 13. Wiesbaden: Harrossowitz, 2009.

Gettys, Travis. "Jon Stewart mocks childish fantasies of 'Noah' critics: Happily ever after? 'Everybody drowns!'” Raw Story. Released 9 April 2014. http://www.rawstory.com/2014/04/jon-stewart-mocks-childish-fantasies-ofnoah-critics-happily-ever-after-everybody-drowns/.

Godawa, Brian. "Darren Aronofsky's Noah: Environmentalist Wacko." Thus spake Godawa. Released 29 October 2012. http:/godawa.com/movies/sci-fifantasy/darren-aronofskys-noah-environmentalist-wacko/.

. "The Subversion of the Serpent in Aronofsky's Noah." Thus spake Godawa. Released 4 April 2014. http://godawa.com/movies/sci-fifantasy/subversion-serpent-aronofskys-noah/.

Goff, Matthew. "Monstrous Appetites: Giants, Cannibalism and Insatiable Eating in Enochic Literature." Journal of Ancient Judaism 1 (2010): 19-42.

"Before the Genesis flood: Enoch's Monstrous Exegesis (Part I)." Noah's Flood. Ancient Stories of Natural Cataclysm. Released 24 January 2014. http://www.floodofnoah.com/\#! monstrous-enoch-watchers/c123v .

"Ben Sira and the Giants of the Land: A Note on Ben Sira 16:7." Journal of Biblical Literature 129 (2010): 645-655.

Goldenberg, David M. The Curse of Ham: Race and Slavery in Early Judaism, Christianity, and Islam. Princeton: Princeton University Press, 2003.

Goldman, Eric A. "Noah' and the Jews." New Jersey: The Jewish Standard. Released 28 March 2014. http://jewishstandard.timesofisrael.com/noah-andthe-jews/?/content/item/noah and the jews /30296.

Greydanus, Steven D. 'Interview: 'Noah' Writer-Director Darren Aronofsky and Co-Writer Ari Handel." National Catholic Register. Released 21 March 2014. http://www.ncregister.com/daily-news/interview-darren-aronofsky-arihandel.

Grossman, Jonathan. Esther: The Outer Narrative and the Hidden Reading. Siphrut 6. Winona Lake, Ind.: Eisenbrauns, 2011. 
Hendel, Ronald S. "Of Demigods and the Deluge: Toward an Interpretation of Genesis 6:1-4." Journal of Biblical Literature 106 (1987): 13-26.

Johnston, Robert K. “The Biblical Noah, Darren Aronofsky's Film Noah, and Viewer Response to Noah: The Complex Task of Responding to God's Initiative." Ex Auditu 30 (2014): 88-112.

Koller, Aaron. Esther in Ancient Jewish Thought. Cambridge: Cambridge University Press, 2014.

Kraeling, Emil G. "The Significance and Origin of Gen 6:1-4," Journal of Near Eastern Studies 6 (1947): 193-208.

Krule, Miriam. "How Biblically Accurate Is Noah?" Slate: Browbeat. Released 28 March 2014. http://www.slate.com/blogs/browbeat/2014/03/28/noah movie biblical accuracy how the darren aronofsky movie departs from.html.

Kugel, James L. A Walk through Jubilees: Studies in the Book of Jubilees and the World of Its Creation. Journal for the Study of Judaism 156. Leiden: Brill, 2012.

Levinson, Bernard M. "A Post-Priestly Harmonization in the Flood Narrative." Pages 113-23 in The Post-Priestly Pentateuch: New Perspectives on its Redactional Development and Theological Profiles. Edited by Federico Giuntoli and Konrad Schmid. Tübingen: Mohr Siebeck, 2015.

Lilly, Ingrid E. "Ila on the Ark?: Emma Watson in Noah." Noah's Flood. Ancient Stories of Natural Cataclysm. Released 28 January 2014. http://www.floodofnoah.com/\#!movie-emma-watson-as-ila-in-noah/c2yc.

Martin, Erica L. "Darren Aronofsky's Noah and Jewish Tradition." Noah's Flood. Ancient Stories of Natural Cataclysm. http://www.floodofnoah.com/\#!noahmovie-jewish-tradition/c1yem.

Masters, Kim. "Rough Seas on 'Noah': Darren Aronofsky Opens Up on the Biblical Battle to Woo Christians (and Everyone Else)." The Hollywood Reporter. Released 12 February 2014. http://www.hollywoodreporter.com /news/rough-seas-noah-darren-aronofsky-679315.

Mattson, Brian. "Sympathy for the Devil." Dr. Brian Mattson The Website: Journal. Released 31 March 2014. http://drbrianmattson.com/journal /2014/3/31/ sympathy-for-the-devil.

Nickelsburg, George W. E. 1 Enoch 1: A Commentary on the Book of 1 Enoch, Chapters 1-36, 81-108. Hermeneia, Minn.: Fortress, 2001.

1 Enoch: The Hermeneia Translation. Minneapolis, Minn.: Fortress Press, 2012.

. "Apocalyptic and Myth in 1 Enoch 6-11," Journal of Biblical Literature 96 (1977): 383-405.

Noth, Martin. A History of Pentateuchal Traditions. Translated by B. W. Anderson. Englewood cliffs, N. J.: Prentice-Hall, 1972.

Odhiambo, Nicholas. "The Nature of Ham's Sin," Bibliotheca Sacra 170 (2013): 154-65.

Petersen, David L. "Genesis 6:1-4, Yahweh and the Organization of the Cosmos," Journal for the Study of the Old Testament 13 (1979): 47-64.

Pleins, J. David. When the Great Abyss Opened: Classic and Contemporary Readings of Noah's Flood. Oxford: Oxford University Press, 2003. 
Schectman, Sarah. "What Was Biblical in the Movie Noah?" Noah's Flood. Ancient Stories of Natural Cataclysm. http://www.floodofnoah.com/\#!noahmovie-what-was-biblical/c123y.

Ska, Jean Louis. "The Story of the Flood: A Priestly Writer and Some Later Editorial Fragments." Pages 1-22 in The Exegesis of the Pentateuch: Exegetical Studies and Basic Questions. Forschungen zum Alten Testament 66. Tübingen: Mohr Siebeck, 2009.

Vanderkam, James C. "The Book of Enoch and the Qumran Scrolls." Pages 25477 in The Oxford Handbook of the Dead Sea Scrolls. Edited by John J. Collins and Timothy H. Lim. Oxford: Oxford University Press, 2010.

Von Rad, Gerhard. Genesis: A Commentary. Translated by John H. Marks. London: SCM Press, 1972.

Weiland, Forrest S. "Literary Clues to God's Providence in the Book of Esther." Bibliotheca Sacra 160 (2003): 34-47.

Wellhausen, Julius. Prolegomena to the History of Israel. Translated by J. Sutherland Black and Allan Menzies. Edinburgh: Black, 1885.

Wenham, Gordon J. Genesis 1-15. Word Biblical Commentary 1. Waco, Tex.: Word Books, Publ., 1987.

Westermann, Claus. Genesis. Translated by David E. Green. London: T\&T Clark International, 1987.

Wetter, Anne-Mareike. "Speaking from the Gaps: The Eloquent Silence of God in Esther," Pages 153-67 in Reflections on the Silence of God: A Discussion with Marjo Korpel and Johannes de Moor. Edited by Bob Becking. Leiden: Brill, 2013.

Wright, Archie T. The Origin of Evil Spirits: The Reception of Genesis 6.1-4 in Early Jewish Literature. 2nd ed. Wissenschaftliche Untersuchungen zum Neuen Testament 198. Tübingen: Mohr Siebeck, 2013.

Yamauchi, Edwin M. Africa and the Bible. Grand Rapids, Mich.: Baker Academic, 2004.

Dr Lydia Lee is a postdoctoral research fellow of the Research Focus Area for Ancient Texts: Text, Context and Reception at the North-West University (Potchefstroom Campus).Email: 1ydia.lee.siqi@gmail.com. 